\author{
Joanna Gadzinowska ${ }^{1}$, Katarzyna Hura ${ }^{2}$, Bożena PaWŁowska ${ }^{3}$, TOMasz Hura ${ }^{1}$ \\ ${ }^{1}$ Instytut Fizjologii Roślin PAN \\ Niezapominajek 21, 30-239 Kraków \\ ${ }^{2}$ Katedra Fizjologii Roślin \\ Wydział Rolniczo-Ekonomiczny \\ Uniwersytet Rolniczy $w$ Krakowie \\ Podłużna 3, 30-239 Kraków \\ ${ }^{3}$ Katedra Roślin Ozdobnych \\ Wydziat Biotechnologii i Ogrodnictwa \\ Uniwersytet Rolniczy $w$ Krakowie \\ Al. 29 Listopada 54, 31-425 Kraków \\ e-mail: j.gadzinowska@ifr-pan.edu.pl \\ t.hura@ifr-pan.edu.pl
}

\title{
Z PÓŁNOCY NA POŁUDNIE, CZYLI INWAZYJNY CHARAKTER RÓŻY RDZAWEJ (ROSA RUBIGINOSA L.)
}

\section{WSTEP}

Róża rdzawa (Rosa rubiginosa L., Syn.: Rosa eglanteria L.), zwana także różą szkocka (ang. sweet briar, eglantine rose), jest krzewem $z$ rodziny różowatych (Rosaceae) (ZIMMERMANN i współaut. 2011, 2012). Należy do róż dziko rosnących w podzwrotnikowej i umiarkowanej strefie półkuli północnej. Naturalne stanowiska tego gatunku obejmuja Azję, prawie cała Europę, Amerykę Północna i północną część Afryki (PoPEK 2002, KHAPUGIN 2015, JAGODZIN̂SKI i współaut. 2016). W Europie znajdują się rodzime stanowiska róży rdzawej (ZIMMERMANN i współaut. 2011, 2012). W XIX i XX w. R. rubiginosa została wprowadzona do Australii, Nowej Zelandii i Ameryki Południowej (ZimmermanN i współaut. 2014), gdzie stała się gatunkiem inwazyjnym o dużej ekspansywności i konkurencyjności w warunkach ekosystemu leśnego i stepowego (CAVALLERO i RAFFAELE 2010). Na półkuli południowej znana jest także jako "rosa mosqueta" i jako tzw. „sweet brier" (HATTON 1989, HorNero-MENDEZ i MingueZ-MOSQUERA 2000, RAMOS i współaut. 2016). W Ameryce Południowej największe stanowiska dziko rosnacych krzewów znajduja sie w Chile i Argentynie (ZIMMERMANN i współ- aut. 2010, 2012). W obrębie naturalnego zasięgu na półkuli północnej tworzy niezbyt liczne populacje, natomiast na opanowanych terenach półkuli południowej gatunek ten zajmuje duże obszary i traktowany jest jako niepożądany „chwast”. Jako gatunek charakteryzujący się dużą ekspansywnością zaczyna dominować $\mathrm{w}$ ekosystemach leśnych i stepowych, wypierajac rośliny rodzime na półkuli południowej (AGUIRRE i współaut. 2009). Duży potencjał inwazyjny róży rdzawej może wynikać m.in. ze specyficznych i bardzo wydajnych mechanizmów aklimatyzacji do niekorzystnych warunków siedliskowych.

\section{KLASYFIKACJA I OPIS BOTANICZNY RÓŻY RDZAWEJ}

Rodzina różowatych (Rosaceae) liczy około 3000 gatunków (POPEK 2002). Ze względu na liczebność i różnorodność gatunków, rodzaj Rosa został podzielony na cztery podrodzaje:

- Hesperhodos Cockerell,

- Platyrhodon (Hurst.) Rehder,

- Hulthemia (Dumort.) Focke.,

- Rosa. 


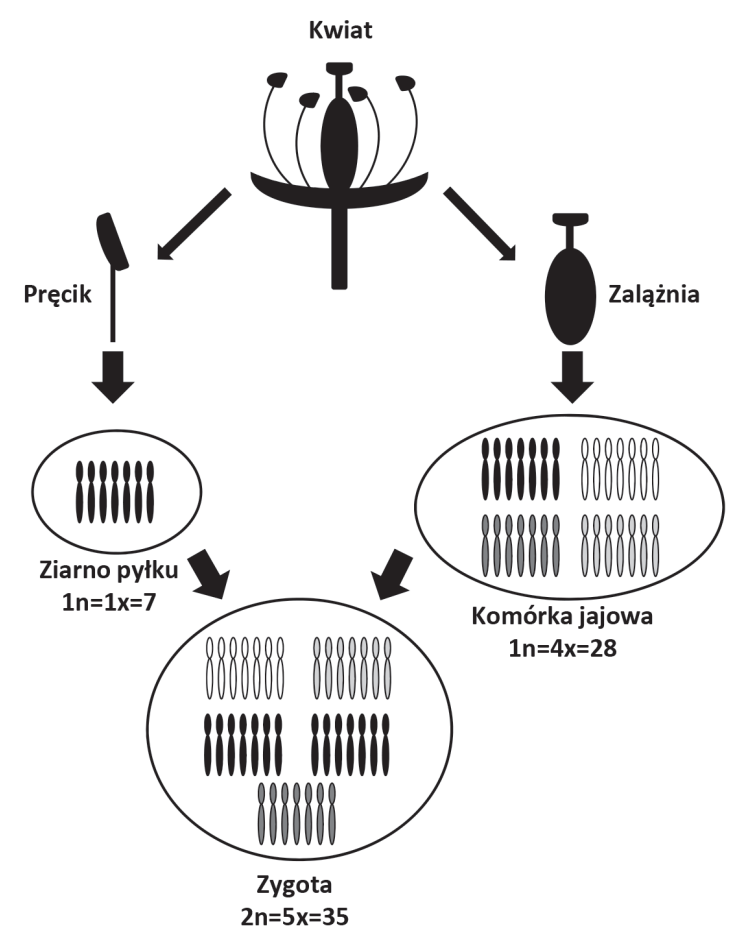

Ryc. 1. Schemat mejozy u róży rdzawej. Powstajace w pylnikach ziarna pyłku zawieraja po 7 chromosomów, natomiast znajdujaca się w zalążni komórka jajowa zawiera 28 chromosomów. Zapłodnienie prowadzi do powstania pentaploidalnej komórki z 35 chromosomami. Chromosomy tworzace pary (biwalenty) oznaczone sa kolorem czarnym, a nie tworzace pary (uniwalenty) kolorem białym, jasnoszarym i ciemnoszarym (wg RiTz i współaut. 2011, zmieniona).

Pierwsze trzy podrodzaje sa reprezentowane przez jeden lub dwa gatunki, natomiast podrodzaj Rosa jest najliczniejszy. W jego obrębie wyróżniono dziesięć sekcji (WISSEMANN i RITZ 2005, NYBOM i WERLEMARK 2017). Sekcja Caninae, do której należy $R$. rubiginosa, reprezentowana jest przez około 50 gatunków i podzielono ja na 6 głównych podsekcji: Rubigineae, Vestitae, Tomentellae, Caninae, Rubrifoliae i Trachyphyllae. Niekiedy wyróżnia się siódma podsekcję, Stylosae (DE Cock i współaut. 2008). Podsekcja Rubigineae, której przedstawicielem jest róża rdzawa, na tle innych podsekcji wyróżnia się m.in. tym, że włoskowate gruczołki na powierzchni liści wydzielaja zapach przypominajacy aromat jabłka (WISSEMANN 2000, DE COCK i współaut. 2008). Warto dodać, że np. w Chile w stosunku do $R$. rubiginosa, $R$. canina, $R$. moschata oraz innych gatunków/odmian rosnacych tam obecnie dziko, stosuje się nazwę „rosa mosqueta” (WERLEMARK 2009).

Sekcja Caninae charakteryzuje się nietypowym przebiegiem mejozy. Większość ga- tunków jest pentaploidalna, ale występuja również róże tetraploidalne i hekspaloidalne. Oznacza to, że moga mieć odpowiednio 28, 35 lub 42 chromosomy (WERLEMARK i współaut. 1999). Róża rdzawa jest pentaploidem zawierającym pięć zestawów chromosomów, z których każdy zawiera po 7 chromosomów, $\mathrm{w}$ sumie $35(2 \mathrm{n}=5 \mathrm{x}=35)$ (POPEK 2007). Tylko dwa zestawy chromosomów tworza biwalenty (pary chromosomów homologicznych), które są równo rozdzielone podczas mejozy pomiędzy komórkę jajowa (7 chromosomów) i ziarno pyłku (7 chromosomów) (Ryc. 1). W żeńskiej części kwiatu pozostałych 21 chromosomów dołączonych zostaje do biwalentów, dlatego komórka jajowa będzie zawierała 28 chromosomów. W ziarnie pyłku 21 uniwalentów (czyli pojedynczych chromosomów) ulega eliminacji, stąd pozostaje tylko 7 biwalentów. Podczas zapłodnienia powstaje odtworzona somatyczna liczba chromosomów (NyBOM i współaut. 2004, KHAITOVA i współaut. 2010). Dziedziczenie jest asymetryczne, ponieważ tylko 15-25\% chromosomów jest przekazywanych z pyłku, zaś pozostałe chromosomy pochodza z komórki jajowej (NYBOM i WERLEMARK 2017).

Róża rdzawa jest krzewem osiagajacym od 0,5 do 3 metrów wysokości (Ryc. 2) (POPEK 2007). W Europie $R$. rubiginosa kwitnie od maja do lipca. Kwiaty tego gatunku maja intensywnie różowy kolor i sa rozmieszczone pojedynczo lub w kwiatostanach (SENETA i DOLATOWSKI 2006). Długopędy pokryte sa kolcami, których nie posiadaja pędy kwiatowe. Nieparzystopierzaste liście złożone sa przeważnie $z 5$ lub 7 drobnych szerokojajowatych listków. Pomarańczowoczerwony owoc tego gatunku zaliczany jest do złożonych owoców rzekomych, u których wewnatrz nibyowocni, powstałej $z$ dna kwiatowego (hypancjum), osadzone sa liczne jednonasienne owocki - niełupki (SENETA 1991, POPEK 2007, RAMOS i współaut. 2016).

\section{RODZIME POPULACJE RÓŻY RDZAWEJ}

Naturalny zasięg występowania $R$. rubiginosa obejmuje strefę umiarkowana i subtropikalna półkuli północnej. Krzewy osiagaja do $3 \mathrm{~m}$ wysokości. Rosna na stanowiskach nasłonecznionych, na glebach zasobnych w wapń. Tworza nieliczne populacje, liczace nie więcej niż 20 osobników. Typowe siedliska występowania to murawy kserotermiczne, miedze, zarośla śródpolne, przydroża, obrzeża lasów, skały oraz zbocza i ściany wąwozów. W Polsce stanowiska tej róży obejmuja obszar całego kraju, zarówno tereny nizinne, jak i górskie do $800 \mathrm{~m}$ n.p.m. W Niemczech i Hiszpanii występuje na wysokości ponad 1000 m n.p.m. (POPEK 2002, ZIMMERMANN 

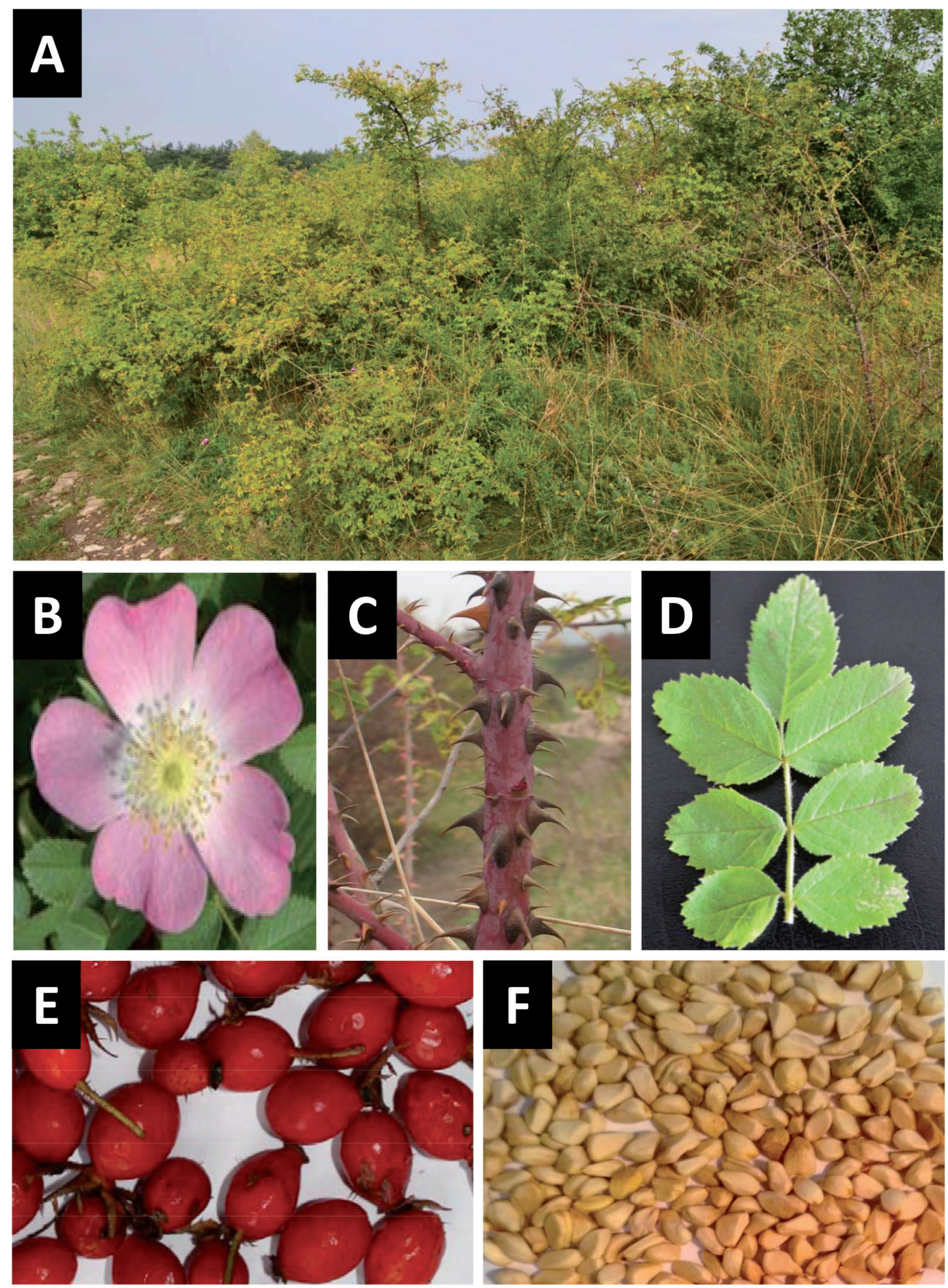

Ryc. 2. Stanowisko róży rdzawej w Pychowicach na terenie Krakowa (A, fot. Tomasz Hura) oraz zbliżenia jej organów: kwiatu (B, fot. Tomasz Hura), łodygi (C, fot. Bożena Pawłowska), liścia (D, fot. Bożena Pawłowska), owocu rzekomego (E, fot. Bożena Pawłowska) i owocu właściwego - jednonasiennej niełupki (F, fot. Bożena Pawłowska). 
i współaut. 2010). Róża rdzawa należy do roślin ciepłolubnych, dlatego głównym zagrożeniem dla tego gatunku jest zarastanie obszarów jej występowania przez drzewa i inne krzewy, które, powoduja eliminację $R$. rubiginosa na skutek ograniczenia dostępu światła. W Republice Mordowii (Rosja) róża rdzawa należy do rzadkich gatunków i $z$ tego powodu wpisano ja do ksiegi gatunków zagrożonych (Red Book of the Republic of Mordovia: Rare species of plants, lichens and fungi) (KHAPUGIN 2015).

\section{INWAZYJNE POPULACJE RÓŻY RDZAWEJ}

Inwazje obcych gatunków miewają poważne skutki ekologiczne, ekonomiczne, a nawet moga mieć negatywny wpływ na zdrowie ludzi (np. ZIMMERMANN i współaut. 2014, GAECZYŃSKA i współaut. 2016, NAJBEREK i SOLARZ 2016). Uważa się, że skutki inwazji biologicznych sa groźniejsze, nawet w porównaniu $z$ konsekwencjami zanieczyszczenia środowiska, kłusownictwa czy nielegalnego handlu rzadkimi gatunkami (SOLARZ 2007).

Wiele roślin inwazyjnych zagraża różnorodności biologicznej w obrębie wtórnego zasięgu, ponieważ wypieraja rodzime gatunki $z$ ich naturalnych stanowisk (GNIAZDOWSKA 2005, CAVALLERO i RAFFAELE 2010). Jednak niektóre ekspansywne gatunki znajduja zastosowanie w działalności człowieka zwiazanej $z$ odbudowa zdegradowanego środowiska (SVRIZ i współaut. 2013).

Do Ameryki Południowej róża rdzawa została prawdopodobnie przywieziona przez hiszpańskich i/lub niemieckich kolonizatorów. Natomiast do Argentyny została wprowadzona na poczatku XX w., gdzie opanowała górskie łaki i tereny leśne oraz stepy, pastwiska i przydroża w Patagonii. R. rubiginosa tworzy tam populacje składajace się z tysięcy osobników, a poszczególne krzewy mogą osiagać wysokość do $10 \mathrm{~m}$. Róża rdzawa stała się tak charakterystycznym elementem krajobrazu Patagonii, że sprzedaje się tam pamiątkowe pocztówki $z$ wizerunkami tej rośliny (SvRIZ i współaut. 2013; ZIMMERMANN i współaut. 2010, 2012, 2014).

W Argentynie traktowana jest jako roślina niepożądana, chociaż dawniej wykorzystywana była do produkcji syropu i paszy dla kóz (SYRETT 1990). Rzekome owoce zbiorowe stanowia pokarm chętnie zjadany przez udomowione i dzikie zwierzęta, skutkiem czego duża liczba niełupek może zostać szybko i efektywnie rozproszona na znaczna odległość (Molloy 1964). Po wstępnej skaryfikacji (uszkodzenie okryw nasiennych) w przewodzie pokarmowym zwierzat i defeka- cji, zawarte w niełupkach nasiona sa gotowe do kiełkowania. Nie bez znaczenia jest fakt, że rodzime dla Argentyny rośliny owocuja w sezonie wiosenno-letnim (na półkuli południowej to okres od września do marca). Natomiast owoce $R$. rubiginosa dojrzewaja pod koniec lata i jesienia (na półkuli południowej to okres od marca do czerwca), dlatego pod koniec sezonu wegetacyjnego hypancja (elementy kwiatów) tego gatunku sa szczególnie chętnie zjadane przez zwierzęta (Cavallero i RafFaele 2010).

Inną przyczyna dynamicznej ekspansji tej róży w Argentynie i Patagonii jest brak naturalnych wrogów (wyspecjalizowanych roślinożerców i patogenów) i konkurencji ze strony innych roślin (DE PIETRI 1992). Przy braku czynników ograniczających (abiotycznych, czy biotycznych) gatunki obce wykazują szybszy wzrost i dużą dynamikę rozprzestrzeniania. Powoduje to często osłabienie konkurencyjności rodzimych roślin i wyparcie ich $z$ ekosystemu (NAJBEREK i SOLARZ 2016).

W porównaniu $z$ innymi przedstawicielami rodziny Rosaceae, róża rdzawa wyróżnia się dużą odpornością na patogeny grzybowe, takie jak Podosphaera pannosa (Wall.: Fr.) de Bary (maczniak prawdziwy róż), Phragmidium spp. (rdza róż), Marssonina rosae (Lib.) Died. (czarna plamistość róż), czy Sphaceloma rosarum (Pass.) Jenkins (plamistość liści, łodyg i owoców). W związu $z$ tym sugeruje się, że $R$. rubiginosa jest gatunkiem charakteryzującym się monogeniczną odpornościa warunkowana przez pojedyncze geny (geny $R)$. Ten typ odporności jest zazwyczaj specyficzny w stosunku do danego patogenu (CASTRO i współaut. 2003, NYBOM i WERLEMARK 2017).

Zasiedlajac zbiorowiska roślinne zakłócone na skutek pożaru, wyrębu lasu czy wypasu zwierzat gospodarskich, $R$. rubiginosa zachowuje się jak roślina pionierska. Na dotkniętym pożarem terenie Parku Narodowego Nahuel Huapi w Patagonii, wszystkie posadzone tam osobniki róży rdzawej kwitły i owocowały już dwa lata po kataklizmie. Natomiast na nienaruszonym terenie kwitło 91\% roślin, a owocowało zaledwie 58\% krzewów (CAVAllero i RAFFAEle 2010). Podobne zjawisko ekspansji róży rdzawej zaobserwowano na terenach Argentyny zdegradowanych przez wycinke drzew, wypas bydła i uprawy. Stwierdzono, że $R$. rubiginosa pojawiła się tam na $70 \%$ zdegradowanego obsza$\mathrm{ru}$, a średnie zagęszczenie populacji wyniosło 2,5 osobnika na $100 \mathrm{~m}^{2}$. Jednocześnie w pobliżu pojedynczych krzewów pojawiały się inne gatunki, wśród których rośliny zielne stanowiły 18\%, a drzewa i krzewy 15\% (DE PIETRI 1992). Okazało się, że na tere- 
nach zdegradowanych róża rdzawa poprawia strukturę gleby. Zapewnia także odpowiednie mikro-środowisko dla rozwoju rodzimych gatunkow przez tworzenie korzystnych warunków świetlnych (zacienianie, rozpraszanie nadmiaru światła, w tym promieniowania UV) oraz wilgotnościowych gleby i powietrza. Stąd uznaje się, że róża ta może być wykorzystana do ochrony innych gatunków roślin rozwijających się w jej najbliższym otoczeniu (ang. nurs plant) (DE PIETRI 1992, SvRIZ i współaut. 2013). Dobrze aklimatyzuje się do stresowych warunków siedliskowych, takich jak deficyt wody i składników mineralnych w glebie, czy zasolenie podłoża. W Chile róża rdzawa doskonale rośnie na terenach o niskiej wartości agronomicznej, na glebach suchych i ubogich (ROBERT i wspó1aut. 2003, HURA i wpółaut. 2017). Duży potencjał zasiedlania przez różę rdzawa suchych, zdegradowanych i niezagospodarowanych terenów jest prawdopodobnie skutkiem uruchamiania przez tą roślinę mechanizmów efektywnego wykorzystywania światła, wody i składników mineralnych (ZIMMERMANN i współaut. 2014, NAJBEREK i SOLARZ 2016). Te możliwości róży rdzawej czynią ją interesującym obiektem badań fizjologicznych, biochemicznych i molekularnych.

Niepewne jest pochodzenie i czas, w którym $R$. rubiginosa została wprowadzona do Nowej Zelandii. Pierwsza wzmianka o tym krzewie pochodzi z 1835 r. Odnotowal to Karol Darwin przebywajacy w położonej na Wyspie Północnej osadzie Paihia. Róża rdzawa była uprawiana w tamtejszym ogrodzie misjonarzy. W większości byli oni Brytyjczykami, dlatego przypuszcza się, że $R$. rubiginosa została sprowadzona do Nowej Zelandii z Wysp Brytyjskich. Uważa się, że to właśnie Anglicy wprowadzili ten gatunek do uprawy jako roślinę ozdobna i jadalną. Jej czerwonawe owoce rzekome były wykorzystywane do produkcji wina i przetworów. Przysmak na angielskich stołach stanowiły również kandyzowane młode pędy róży (Molloy 1964). Róża rdzawa rozprzestrzeniła się na terenie Nowej Zelandii dzięki m.in. kitance lisiej (Trichosurus vulpecula Kerr) i kosom (Turdus merula L.), dla których owoce rzekome róży stały się składnikiem diety (RouCO i NORBURY 2013).

$R$. rubiginosa w Australii i w Nowej Zelandii jest groźną rośliną inwazyjną. Od 1919 r. do chwili obecnej jest uznawana za jeden z 20 najgroźniejszych chwastów w Nowej Południowej Walii (HATTON 1989). W 1987 r. róża rdzawa znalazła się na 14 . miejscu wśród gatunków stanowiących najpoważniejsze zagrożenie dla naturalnych ekosystemów Nowej Zelandii (SYRETT 1990). Już od 1960 r. podejmowano tam próby biologicznego zwalczania niektórych gatunków inwazyjnych, w tym róży rdzawej. Do ograniczania rozwoju inwazyjnej populacji krzewu próbowano wykorzystać znamionka różanego (Megastigmus aculeatus Swederus), owada, który prawdopodobnie pojawił się w Nowej Zelandii razem $z$ różą. Jego larwy rozwijaja się i żerują w nasionach. Okazał się jednak, że $M$. aculeatus nie zatrzymał ekspansji róży rdzawej. Do biologicznego zwalczania róży próbowano wykorzystać także szypszyńca różanego (Diplolepis rosae L.), ale projekt wdrożenia tej metody nie zostat zrealizowany (HARMAN i współaut. 1996, RoUCO i NORBURY 2013).

\section{POZYTYWNE OBLICZE RÓŻY RDZAWEJ}

Róża rdzawa jest źródłem wielu wartościowych zwiazków organicznych, dlatego wykorzystuje się ja w przemyśle farmaceutycznym i kosmetycznym. Ekstrakty $z$ owoców rzekomych róż mają działanie przeciwbakteryjne, przeciwgrzybicze, przeciwzapalne i wykazują aktywność antyoksydacyjną. Zawieraja duże ilości kwasów organicznych (głównie kwasu askorbinowego), flawonoidów, karotenoidów i garbników. W porównaniu $z$ innymi gatunkami $z$ sekcji Caninae, róża rdzawa charakteryzuje się najwyższa zawartością flawonoidów (około 91\%) oraz wysokim poziomem kwasu cytrynowego (60\%) i kwasu askorbinowego (40\%) (ADAMCZAK i współaut. 2012, KRÓL i współaut. 2012). Kremy na bazie róży stosowane sa do regeneracji skóry po zabiegach i oparzeniach (FRANCO i współaut. 2007). Liście i płatki wykorzystuje się do przygotowania kapieli leczniczych oraz naparów do picia ze względu na właściwości ściagające i orzeźwiające (RAMOs i współaut. 2016). Z nasion róży wytwarzany jest olej o wysokiej zawartości kwasu a-linolenowego (45-50\%) i linolowego (około 40\%). Oba te związki moga być wykorzystywane do poprawy stanu skóry; nawilżaja oraz przyspieszaja regenerację i gojenie ran (HORNERO-MENDEZ i MINGUEZ-MOSQUERA 2000, AGUIRRE i współaut. 2016, RAMOS i współaut. 2016). Określono również główne składniki olejku eterycznego wyizolowanego z owoców rzekomych róż. Jego organicznymi składnikami sa: witispiran, cis-3-hexenal, kwas dodekanowy, kwas heksadekanowy, 6-metylo-5-hepten-2-on, $\beta$-jonon, dokozan, a-E-akaridial, kwas linolowy i kwas myristykowy. Wykazano, że róża rdzawa kumuluje duże ilości kwasu heksadekanowego (4,7626,37\%) i witispiranu (1,95-32,84\%) (KRÓL i współaut. 2012).

Owoce rzekome róży rdzawej wykorzystywane są w przetwórstwie spożywczym do produkcji dżemów o wysokiej zawartości 
witaminy C. Owoce tego gatunku zawieraja piętnaście razy więcej tej witaminy $\mathrm{w}$ porównaniu $z$ owocami cytrusowymi (HORNERO-MENDEZ i MingueZ-Mosquera 2000). Najwięcej kwasu askorbinowego kumuluje się podczas dojrzewania w owocach rzekomych. Zawieraja one wapń, potas, sód, antyoksydanty i tokoferole, stanowiace równie bogate źródło likopenu i $\beta$-karotenu, jak pomidory i korzenie marchwi (HoRNERO-MENDEZ i MINGUEZ-MOSQUERA 2000, FRANCO i współaut. 2007, AGUIRRE i współaut. 2016, RAMOS i współaut. 2016, NYBOM i WERLEMARK 2017).

Róża rdzawa może służyć jako odporna na choroby i szkodniki podkładka do szczepienia. Bywa sadzona $\mathrm{w}$ centrach miast, wykorzystuje sie ja do komponowania zieleni przydrożnej. Ze względu na duża odporność na niekorzystne warunki siedliskowe i zanieczyszczenia metalami ciężkimi, stanowi cenny materiał szkółkarski (POPEK 2002, HURA i współaut. 2017). W ostatnich latach prowadzone sa badania nad wykorzystaniem $R$. rubiginosa do produkcji biopaliw. Ich wyniki potwierdzaja duże możliwości zastosowania nasion i miąższu owoców rzekomych do produkcji paliw typu biodiesel (RAmOs i współaut. 2016).

Podsumowujac, R. rubiginosa charakteryzuje się wysoka zawartościa witaminy $\mathrm{C}$ w owocach rzekomych, dużymi możliwościami przystosowawczymi do niekorzystnych warunków środowiska, odpornościa na patogeny grzybowe oraz abiotyczne czynniki stresowe. Dla południowej półkuli jest to gatunek inwazyjny, wypierający rodzima roślinność $z$ ekosystemów leśnych i stepowych. Jednak róża rdzawa to również roślina pożyteczna, gdyż może być wykorzystywana do obsadzania terenów zdegradowanych.

\section{Streszczenie}

Róża rdzawa (Rosa rubiginosa) charakteryzuje sie nietypowym przebiegiem mejozy oraz dużą odpornościa na działanie abiotycznych czynników stresowych. Naturalny zasięg tego gatunku obejmuje półkulę północna (cała Europa, Ameryka Północna, azjatycka część Rosji), gdzie tworzy niezbyt liczne populacje. Występuje głównie na nasłonecznionych stanowiskach i glebach zasobnych w wapń. Rosa rubiginosa została także wprowadzona na półkulę południowa - do Ameryki Południowej, Australii i Nowej Zelandii, gdzie stała się gatunkiem inwazyjnym zdolnym do wypierania rodzimych roślin. Na półkuli południowej uważana jest za gatunek niepożądany - „chwast”, jednak jest to również roślina pożyteczna. Występuje jako roślina pionierska wkraczająca na obszary zdegradowane przez katastrofy ekologiczne i na skutek działalności człowieka. Może być wykorzystywana do ochrony innych gatunków roślin rozwijajacych się w jej sasiedztwie, zapewniając im odpowiednią wilgotność gleby i powietrza, a także właściwe warunki świetlne. W artykule zwraca się uwagę na duże możliwości aklimatyzacji róży rdzawej do stresów środowiskowych.

\section{LITERATURA}

ADAMCZAK A., BUCHWALD W., ZiELIŃSKI J., MielCAREK S., 2012. Flavonoid and organic acid content in rose hips (Rosa L., sect. Caninae DC. EM. Christ.). Acta Biol. Crac. Ser. Bot. 54, 105-112.

Aguirre G. U., Ciuffo G. M., Ciuffo L. EC., 2009. Genetic differentiation of Rosa rubiginosa $L$. in two different Argentinean ecoregions. Plant Syst. Evol. 281, 183-192.

AguirRe G. U., Loza M., Gasquez J., Fusco M., Sosa A., CiUffo G. M., CiUfFo L. E., 2016. The potentiality of non timber forest products. Fruit availability, phytochemical properties of Rosa rubiginosa L. rose hips. Am. J. Plant Sci. 7, 2272-2287.

Castro A. J., Capettini F., Corey A. E., Filichimna T., Hayes P. M., Kleinhofs A., Kudrna D., RICHARDSON K., SANDOVAL-ISLAS S., ROSSI C., VIVAR H., 2003. Map ping and pyramiding of qualitative and quantitative resistance to stripe rust in barley. Theor. Appl. Genet. 107, 922930

Cavallero L., Raffaele E., 2010. Fire enhances the 'competition-free' space of an invader shrub: Rosa rubiginosa in northwestern Patagonia. Biol. Invasions 12, 3395-3404.

De Cock K., VAnder MiJnsbrugGe K., BReyne P., VAN Bockstaele E., VAN Slycken J., 2008. Morphological and AFLP-based differentiation within the taxonomical complex section $\mathrm{Ca}$ ninae (subgenus Rosa). Ann. Bot. 102, 685697.

DE PIETRI D. E., 1992. Alien shrubs in a national park: can they help in the recovery of natural degraded forest? Biol. Conserv. 62, 127-130.

Franco D., PINELO M., SinEIRO J., NUNEZ M. J., 2007. Processing of Rosa rubiginosa: extraction of oil and antioxidant substances. Bioresour. Technol. 98, 3506-3512.

GALCZYŃSKA M., GAMRAT R., ŁYSKO A., 2016. Wpływ gatunków inwazyjnych $\mathrm{z}$ rodzaju $\mathrm{He}$ racleum spp. (Apiaceae) na środowisko i zdrowie człowieka. Kosmos 65, 591-599.

GNIAZDOWSKA A., 2005. Oddziaływania allelopatyczne - „nowa bron” roślin inwazyjnych. Allelopathic effects - a "new weapon" of invasive plants. Kosmos 54, 221-226.

HARMAN H. M., SYretT P., Hill R. L., Jessep C. T., 1996. Arthropod introductions for biological control of weeds in New Zealand, 1929-1995. N. Z. Entomol. 19, 71-80.

HATTON T. J., 1989. Spatial patterning of sweet briar (Rosa rubiginosa) by two vertebrate species. Austral Ecol. 14, 199-205.

HoRNERO-MENDEZ D., MingueZ-Mosouera M. I., 2000. Carotenoid pigments in Rosa mosqueta hips, an alternative carotenoid source for foods. J. Agric. Food Chem. 48, 825-828.

Hura T., SZEWCZYK-TARANEK B., HuRA K., NOWAK K., PAWŁowska B., 2017. Physiological responses of Rosa rubiginosa to saline environment. Water Air Soil Pollut. 228, 81.

JAGODZIŃSKI A. M., MACIEJEWSKA-RUTKOWSKA I., WROŃSKA-PILAREK D., BOCIANOWSKI J., 2016. Taxonomic significance of achene morphology of selected Rosa taxa (Rosaceae) occurring in Poland. Acta Soc. Bot. Pol. 85, 3493.

KHAITOVA L., WERLEMARK G., NYBOM H., KOVARIK A., 2010. Frequent silencing of rDNA loci on the univalent-forming genomes contrasts with their stable expression on the bivalent-forming genomes in polyploid dogroses (Rosa sect. Caninae). Heredity 104, 113-120. 
KHAPUGIN A. A., 2015. Seed mass and seed yield of six roses (Rosa L., Rosaceae Adans.) from central Russia (Republic of Mordovia). Plant Breed. Seed Sci. 71, 13-22.

KRÓl D., ADAMCZaK A., BuchWald W., 2012. Determination of chemical composition of essential oils isolated from hips of native rose species in Poland. Post. Fitoter. 4, 216-219.

Molloy B. P. J., 1964. Soil genesis and plant succession in the subalpine and alpine zones of Torlesse Range, Canterbury, New Zealand. N. Z. J. Bot. 2, 143-76.

NAJBEREK K., SOlARZ W., 2016. Gatunki obce. Przyczyny inwazyjnych zachowan $i$ sposoby zwalczania. Kosmos 65, 81-91.

NyBOM H., WERLEMARK G., 2017. Realizing the potential of health-promoting rosehips from dogroses (Rosa sect. Caninae). Curr. Bioact. Compd. 13, 3-17.

NyBom H., ESSELINK G. D., WERLEMARK G., VoSMAN B., 2004. Microsatellite DNA marker inheritance indicates preferential pairing between two highly homologous genomes in polyploid and hemisexual dog-roses, Rosa L. Sect. Caninae DC. Heredity 92, 139-150.

POPEK R., 2002. Róże dziko rosnace Polski. Plantpress, Kraków.

POPEK R., 2007. Dziko rosnace róże Europy. Officina Botanica, Kraków.

Ramos P. M., Gil J. M., Ramos Sanchez M. C., NAVAS GRACIA L. M., HERNANDEZ NAVARRO S. GIL M., JAVIER F., 2016. Vibrational and thermal characterization of seeds, pulp, leaves and seed oil of Rosa rubiginosa. B. Soc. Argent. Bot. 51, 429-439.

Ritz C. M., KÖHNen I., GROTh M., Theissen G., WISSEMANN V., 2011. To be or not to be the odd one out-allele-specific transcription in pentaploid dogroses (Rosa L. sect. Caninae (DC.) Ser). BMC Plant Biol. 23:11-37.

RoberT P., CARLsSON R. M., ROMERO N., MASSON L., 2003. Stability of spray-dried encapsulated carotenoid pigments from rosa mosqueta (Rosa rubiginosa) oleoresin. J. Am. Oil Chem. Soc. 80, 1115-1120.

Rouco C., NORBURY G., 2013. An introduced species helping another: dispersal of a rose seed infesting wasp by a marsupial in New Zealand. Biol. Invasions 15, 1649-1652.

Seneta W., 1991. Drzewa $i$ krzewy liściaste. Wydawnictwo Naukowe PWN, Warszawa, Tom 1, s. 37.

Seneta W., Dolatowski J., 2006. Dendrologia. Wydawnictwo Naukowe PWN, Warszawa, s. 284.
SOLARZ W., 2007. Inwazje biologiczne jako zagrożenie dla przyrody. Post. Ochr. Roślin 7, 128-133.

Svriz M., Damascos M. A., Zimmermann H., HenSEN I., 2013. The exotic shrub Rosa rubiginosa as a nurse plant. Implications for the restoration of disturbed temperate forests in Patagonia, Argentina. For. Ecol. Manage. 289, 234-242.

SYRETT P., 1990. The rose seed chalcid Megastigmus aculeatus Swederus (Hymenoptera: Torymidae) on sweet brier, Rosa rubiginosa, in the South Island tussock country. N. Z. Entomol. $13,34-38$.

WERLEMARK G., 2009. Dogrose: Wild plant, bright future. Chron. Horticult. 49, 8-13.

Werlemark G., UgGla M., NYBOM H., 1999. Morphological and RAPD markers showed a highly skewed distribution in a pair of reciprocal crosses between hemisexual dogroses, Rosa section Caninae. Theor. Appl. Genet. 98, 557563.

WisSEMANN V., 2000. Epicuticular wax morphology and the taxonomy of Rosa (section Caninae, subsection Rubiginosae). Plant Syst. Evol. 221, 107-112.

WissemanN V., RiTZ C. M., 2005. The genus Rosa (Rosoideae, Rosaceae) revisited: molecular analysis of nrITS-1 and atpB-rbcL intergenic spacer (IGS) versus conventional taxonomy. Bot. J. Linn. Soc. 147, 275-290.

ZimmermanN H., Ritz C. M., HiRsch H., RENISON D., Wesche K., Hensen I., 2010. Highly reduced genetic diversity of Rosa rubiginosa L. populations in the invasive range. Int. J. Plant Sci. 171, 435-446.

Zimmermann H., Von Wehrden H., Damascos M. A., BRAN D., Welk E., Renison D., Hensen I., 2011. Habitat invasion risk assessment based on Landsat 5 data, exemplified by the shrub Rosa rubiginosa in southern Argentina. Austral Ecol. 36, 870-880.

ZIMMERMANN H., VON WEHRDEN H., RENISON D., Wesche K., WelK E., Damascos M. A., HeNSEN I., 2012. Shrub management is the principal driver of differing population sizes between native and invasive populations of Rosa rubiginosa L. Biol. Invasions 14, 2141-2157.

ZimmermanN H., BRANDT P., FischeR J., WelK E., VON WEHRDEN H., 2014. The Human Release Hypothesis for biological invasions: human activity as a determinant of the abundance of invasive plant species. F1000Res. 3, 109. 
KOSMOS Vol. 67, 4, 759-766, 2018

\author{
Joanna Gadzinowska ${ }^{1}$, Katarzyna Hura ${ }^{2}$, Bożena Paweowska ${ }^{3}$, TOMasz Hura ${ }^{1}$
}

${ }^{1}$ The Franciszek Górski Institute of Plant Physiology PAS, 21 Niezapominajek Str., 30-239 Kraków, ${ }^{2}$ Department of Plant Physiology, Faculty of Agriculture and Economics, University of Agriculture in Kraków, 3 Podłużna Str., 30-239 Kraków, ${ }^{3}$ Department of Ornamental Plants, Faculty of Biotechnology and Horticulture, University of Agriculture in Kraków, Al. 29 Listopada 54, 31-425, Kraków,E-mail: j.gadzinowska@ifr-pan.edu.pl, t.hura@ifr-pan.edu.pl

FROM THE NORTH TO THE SOUTH: ON THE INVASIVE NATURE OF ROSA RUBIGINOSA

\title{
Summary
}

Sweet briar (Rosa rubiginosa L.) is characterized by an unusual course of meiosis, resistance to fungal pathogens and high tolerance to abiotic stresses. It is native to the Northern Hemisphere (Europe, North America, and Asian part of Russia), where it forms small-scale populations. The shrub prefers sunny sites and calcium-rich soils. Rosa rubiginosa has been introduced to the Southern Hemisphere (South America, Australia, New Zealand), where it is an invasive species capable of displacing native vegetation. In this part of the world it is considered a weed, but it is also a pioneering plant that colonizes areas degraded by ecological disasters and human activity. It protects nearby plant species by providing them with adequate soil and air humidity and light conditions. This paper discusses the huge potential of sweet briar in acclimatization to environmental stresses.

Key words: biological invasions, Canina-meiosis, environmental threats, pioneer plant 